\title{
Commonplace
}

\section{The Values of Library \\ Publishing and Open \\ Infrastructure: Recapping}

\#LPForum21

\section{Arthur Boston 1}

${ }^{1}$ Scholarly Communication Librarian, Murray State University

Published on: Jun 02, 2021

DOI: $10.21428 / 6 \mathrm{ffd} 8432 . \mathrm{d} 5010 \mathrm{acd}$

License: Creative Commons Attribution 4.0 International License (CC-BY 4.0). 
It was my honor to serve on the planning committee for the 8th annual Library Publishing_Forum (\#LPForum21), held virtually the week of May 10, 2021. I could not have ended my Fellowship with the Library Publishing Coalition on a higher note. The Forum showcased its usual array of superb practical case studies on subjects as varied as open access journals produced by the Chinese American Librarians Association, Black Lives Matter-themed Wikipedia Edit-a-thons, and open-source preprint platforms. One of the major themes recurring throughout the week was the question of who leads, participates in, and is served by global knowledge infrastructure.

The conference began with the opening keynote address delivered by Elaine L. Westbrooks (Vice Provost of University Libraries and University Librarian, University of North Carolina at Chapel Hill) who recounted her attendance at society meetings. There, she observed that profit was often playing too central a role in conversations about new and continuing publications. Westbrooks noted that societies, especially smaller ones, rarely understood the full set of options available to them, such as partnerships with libraries for publishing services. Instead of focusing attention on "self-preservation," Westbrooks said societies should be considering whether or not they could achieve desirable impact; in the wake of a national and global racial reckoning, business models should not simply recreate the old exclusionary ways.

The truth of this fact was made plain as Megdi Abebe, Joyce Gabiola, Sofia Leung, and Kristina Santiago of $\underline{u} \underline{p / / r o o t}$ (a We Here publication) recounted their often hurtful experiences as BIPOC scholars working in academic knowledge production, an overwhelmingly white industry. [Note: pick up Sofia's new work!] Joyce Gabiola posed the rhetorical question of whether our care in publishing was being "centered on the product or the person." The notion of care for the person over the product was later echoed by Caro Ncube (University of Cape Town) who described our scholarly system as constrained by old ways of evaluating scholarship that early-career researchers are not able to challenge.

\section{Visit the web version of this article to view interactive content.}

In the same panel (including University of Cape Town scholars, Jill Claassen, Omo Oaiya, and Anna Leonard), moderator Reggie Raju said that the "Open Access movement has betrayed Africa, that Africa needs to explore an Africanised conceptualization of OA, and that an African OA movement must develop a philosophy 
and purpose that is relevant to the African environment and its challenges." It may be vital for the overall health of the global scholarly system that Africa tackle the access problem in their own way, rather than follow the path that Global North institutions have decided upon that may be "good for groups who sign them but bad for the overall system." As Raju has told us aggain and again, turning subscription budgets into APC budgets is not transformative; it leads to systematic northernization of publishing, marginalizing research voices from the Global South.

\section{Visit the web version of this article to view interactive content.}

Dave Ghamandi (Open Publishing Librarian, University of Virginia) spoke most pointedly on the topic of transformative deals at the Forum. Ghamandi applied a materialist analysis to so-called transformative agreements, noting that they leave the means of production in place "often in the hands of the oligopoly." They serve only established interests and, as a means of reform, they are as illusionary figures of change as sensitivity training and body cams have been in response to police killings of Black men. Payment of high-priced Article Processing Charges by universities who turn around and underfund their library publishing units-that are producing no-APC open access research-represents a new contradiction, Ghamandi concluded.

In my own session, I described an alternative proposal for how elite institutions could spend their money to open readership in a more equitable manner than transformative agreements. I also presented a challenge to the big five publishers to devote $2.5 \%$ of their annual profit margins, or higher, into a pool governed by a stakeholders group (not to include them) focused on investing in open infrastructure and its labor. These funds could go toward supporting any of the locally adoptable tools, platforms, or standards that the Scholarly Communication Technology Catalog ( cataloged.

\section{Visit the web version of this article to view interactive content.}

In the Forum's closing keynote, Kaitlyn Thaney (Executive Director, Invest in Open Infrastructure) described the current system for scholarly research and knowledge production as being "geared towards commoditization" and "perpetuating a system that rewards prestige, exclusion, and walled gardens." She said, to create "equitable and accessible participation in knowledge production and dissemination," our 
infrastructure needs to be "similarly designed." Shifting our "reliance from players misaligned with core values of the community, transparency, and collective responsibility" is how we get there, Thaney concluded.

Overall, the 2021 Library_Publishing_Forum was a success and I look forward to attending the 2022 Forum to hear how presenters integrate this year's clear and forthright statements on racial justice, open infrastructure, and knowledge equity. Identifying and calling out bad actions is a necessity, but must be coupled with the support (vocal, monetary, and continual) for communities engaged in the care and practice of equitable knowledge systems.

I want to thank my fellow program committee members: Justin Gonder, Robin Bedenbaugh, Sonya Betz, Jason Boczar, Jane Buggle, Johanna Meetz, Regina Raboin, Lauren Collister, and David Scherer. Much appreciation for all of the around-thescenes work by Educopia staff: Melanie Schlosser, Caitlin Perry, Hannah Ballard, Nancy Adams, and Brandon Locke. Thanks to Educopia Institute Executive Director Dr. Katherine Skinner and the LPC Board for all the opportunities. 